\title{
O VELHO CHICO E SUAS BORDAS CULTURAIS: AS VOZES POÉTICAS DA CANOA SIDÓ E OUTRAS PERSONAGENS FANTÁSTICAS DO RIO SÃO FRANCISCO NO FILME ESPELHO D'ÁGUA
}

\author{
Velho Chico and its cultural edges: the poetic voices of the Canoe Sidó and other \\ fantastic characters of San Francisco river in the movie Espelho d'água
}

\author{
Nerivaldo Alves Araújo \\ https://orcid.org/0000-0001-9423-3603 \\ Universidade do Estado da Bahia, Departamento de Ciências Humanas, Programa de Pós- \\ Graduação em Estudo de Linguagens, Salvador, BA, Brasil. 41150-000 - ppgel@listas.uneb.br
}

Resumo: Pelas águas imaginárias do Velho Chico navegam uma série de histórias, as quais muitas são compostas de personagens fantásticas como a Mãe d'Água, o Nego d'Água, o Minhocão e outros. Será utilizado como corpus de análise o filme Espelho d'Água: uma viagem no Rio São Francisco (2004), dirigido por Marcus Vinicius Cezar, no qual, se destaca como narradora a personagem Sidó, uma canoa velha, que, juntamente com outros personagem fantásticos, por meio de suas vozes poéticas, tecem a trama envolvente da narrativa fílmica. Tais personagens influenciam diretamente na vida da maioria dos ribeirinhos, os quais tomam os ensinamentos e exemplos das narrativas como modelos de conduta e de vivência. Assim, pretende-se refletir sobre o cunho moralizante, a importância e o lugar de representação ideológica que essas personagens e narrativas ocupam nessas comunidades ribeirinhas, uma vez que, por serem de autoria coletiva, presentes também em uma memória coletiva, contribuem diretamente para a manutenção das tradições e construção das identidades culturais. Tais personagens fazem parte de uma trama cultural diversa, a qual se situa, como versa Jerusa Pires, nas bordas, mas que, pela sua força, vem se firmando, indo em direção a um centro de reconhecimento. Como procedimento metodológico, amparou-se em uma leitura de teóricos que discutem sobre memória, identidades, cultura, narrativas fantásticas e outros aportes pertinentes. Depois, partiu-se para uma análise do filme, quando se buscou fazer uma leitura detalhada dessas personagens fantásticas associando com seu papel e importância na cultura ribeirinha. Além disso, é válida também a experiência do autor desse texto, o qual é pesquisador de narrativas orais semelhantes às trazidas nesse filme, tendo desenvolvido pesquisa qualitativa e etnográfica na região de Xique-Xique, Bahia. Por fim, pode-se chegar à conclusão de que essas personagens fantásticas presentes no filme ou mesmo nas narrativas orais analisadas fazem parte do cotidiano dos ribeirinhos das margens do Velho Chico, tornando-se seres integrantes dessas comunidades, nas quais uma grande maioria, como se percebe no filme e também em depoimentos colhidos em Xique-Xique, trazem um testemunho de histórias que viveram ou ouviram contar sobre tais personagens.

Palavras-chave: Velho Chico. Espelho d'água. Vozes poéticas. Identidades. Cultura das bordas.

Abstract: Through the imaginary waters of Velho Chico, a series of stories navigate, many of which are composed of fantastic characters like Mãe d'Água, o Nego d'Água, o Minhocão and others. The film Espelho d'Água: a trip in San Francisco River (2004), directed by Marcus Vinicius Cezar, will be used as corpus of analysis, in which the character Sidó, an old canoe, stands out as narrator along 
with other fantastic character, through their poetic voices, weave the enveloping plot of the film narrative. Such characters directly influence the lives of most riverine people, who take the teachings and examples of narratives as models of conduct and experience. Like this, it is intended to reflect on the moralizing nature, the importance and the place of ideological representation that these characters and narratives occupy in these riverside communities, once, being of collective authorship, also present in a collective memory, directly contribute to the maintenance of traditions and the construction of cultural identities. Such characters are part of a diverse cultural plot, which is situated, as says Jerusa Pires, at the edges, but which, by its strength, has been steadily moving towards a recognition center. As methodological procedures, it was supported by the reading of theorists who discuss memory, identities, culture, fantastic narratives and other relevant contributions. Then, the film was analyzed, when it was intended to read more detailedly these fantastic characters associating them with their role and importance in the riverside culture. In addition, it is also worthy the experience of the author of this paper, who is a researcher of oral narratives, similar to those brought in this film, having developed qualitative and ethnographic research in the region of Xique-Xique, Bahia. Lastly, one can conclude that these fantastic characters, present in the movie or even in the oral narratives analyzed, make part of the the daily life of the riverine in Velho Chico, and become members of these communities, in which their vast majority, as can be seen from the film and also from testimonials collected in Xique-Xique, bring a testimony of stories they have lived or heard about such characters.

Keywords: Velho Chico. Espelho D’água. Poetic Voices. Identities. Culture of edges.

\section{Introdução}

As águas imaginárias do Velho Chico encantam e fascinam a todos que integram a mesma comunidade narrativa das margens do São Francisco. Uma vez que não é visto como simplesmente um rio, prefiro chamá-lo aqui de Velho Chico, conforme carinhosamente é chamado pela maioria daqueles que habitam as suas margens ou navegam pelas suas águas encantadas. Ora, o Velho Chico, portanto, não se contenta apenas em ser um rio no sentido de um curso que a água faz até chegar a outro rio ou ao mar. Ele, o Velho, assume qualificações de gente, de ser com sentimentos, desejos e atitudes reveladas em narrativas contadas por aqueles que o conhecem, que convivem consigo em suas margens e/ou águas.

Assim, ele deixa de ser visto como apenas um cenário, um local, um curso d’água, mas também como um ser que, juntamente com outras personagens fantásticas as quais habitam as suas águas e margens, permeiam o imaginário ribeirinho de histórias e acontecimentos contados e testemunhados por vários narradores de suas margens. Fazse oportuno, então, tecer uma referência à narrativa fantástica como aquela que, segundo Todorov (2014), é uma obra que apresenta como uma das funções fundamentais do gênero a hesitação entre a realidade e a fantasia que a narrativa deve provocar no leitor. Essa hesitação, por conseguinte, se dá pelo fato de a narrativa fantástica conter um enredo povoado de elementos sobrenaturais, objetos mágicos, animais encantados, entre outros. Sendo assim, as personagens qualificadas nesse estudo como fantásticas se enquadram nesse gênero da literatura, podendo ser chamadas de seres fantásticos, já que são encantadas e assumem características humanas.

É preciso considerar que o gênero fantástico trazido aqui, conforme o próprio Todorov (2014), encontra-se numa linha tênue de dois subgêneros: o estranho e o maravilhoso. 
Porém, como não podemos, nas narrativas aqui apresentadas, explicar os acontecimentos sobrenaturais pelas próprias leis da natureza e os aceitamos como o são, já que não se explica de nenhuma maneira, falamos a partir de uma aproximação de tais narrativas ao fantástico maravilhoso.

Desse modo, quem é que não ouviu falar do Nego d’Água, da Mãe d'Água, do Minhocão, dentre outros seres fantásticos do Rio São Francisco? Então, o propósito dessa discussão nos remete à canoa Sidó, uma personagem narradora que nos apresenta a trama e as personagens do filme Espelho d’Água: uma viagem no Rio São Francisco (2004), dirigido por Marcus Vinicius Cezar.

No enredo dessa obra fílmica, que tem como enfoque principal o romance entre a personagem Henrique (ator Fábio Assunção) e a personagem Celeste (atriz Carla Regina), a canoa Sidó se destaca como a guardiã das memórias ribeirinhas, pois detém o conhecimento sobre o rio, suas histórias e memórias.

Tais personagens que integram o universo fantástico maravilhoso do imaginário do Velho Chico influenciam diretamente na vida da maioria dos ribeirinhos, os quais tomam os ensinamentos e exemplos das narrativas como modelos de conduta e de vivência. São elementos ideológicos, valores e crenças que contribuem para a formação das identidades culturais desses povos que, conforme Hall (2000), se estabelecem a partir da interação do indivíduo com o outro, com o meio e suas influências. Essas personagens fazem parte de uma trama cultural diversa, a qual se situa, como versa Jerusa Pires Ferreira (2010), nas bordas, mas que, pela sua força, vem se firmando, indo em direção a um centro de reconhecimento.

Assim, pretende-se refletir sobre o cunho moralizante, a importância e o lugar de representação ideológica que essas personagens e narrativas ocupam nessas comunidades ribeirinhas, uma vez que, por serem de autoria coletiva, presentes também em uma memória coletiva, contribuem diretamente para a manutenção das tradições e construção das identidades culturais. Dessa forma, torna-se possível, ainda, visualizar o lugar ocupado e a força que essa cultura das bordas exerce na construção das identidades e na manutenção das tradições.

O percurso metodológico seguido para tal pesquisa seguiu o curso da pesquisa bibliográfica na qual se amparou, em uma leitura de teóricos que discutem sobre memória, identidades, cultura, narrativas fantásticas e outros aportes pertinentes. Ademais, partiu-se para uma análise do filme, quando se buscou fazer uma leitura detalhada dessas personagens fantásticas associando com seu papel e importância na cultura ribeirinha. Integrando as atividades metodológicas, vale considerar também a experiência do autor desse texto, o qual é pesquisador de narrativas orais semelhantes às trazidas nesse filme, tendo desenvolvido pesquisa qualitativa e etnográfica na região de Xique-Xique, Bahia.

\section{A voz poética de Sidó em suas narrativas}

Na narrativa fílmica, Sidó é a detentora da voz poética que narra, que perpetua a 
memória ribeirinha e a protege da submersão nas águas do esquecimento, pois "a destruição de velhas culturas veneráveis desnuda a humanidade inteira, despossuída de seu trabalho milenar, de sua memória, de seus mortos [...]" (ZUMTHOR, 2010, p. 315).

Dessa forma, a canoa se torna a voz guardiã e transmissora, que não se cala, assumindo um papel de griote, mesmo configurando-se como um personagem fantástico maravilhoso que habita o imaginário das comunidades das margens do Rio São Francisco. Assim, Sidó, uma das próprias personagens do imaginário popular ribeirinho, na narrativa fílmica, age, portanto, como mantenedora da tradição oral, pela voz de narradora que lhe é dada. É oportuno informar aqui que, conforme Barzano (2013), griote é o feminino de griot, uma palavra de origem francesa, de uso habitual no noroeste da África, na região do Mali, cuja colonização foi feita pela França. Já o termo "griótica", originado do francês griotique, foi criado e inicialmente usado no teatro africano. Segundo Amarino Oliveira de Queiroz (2007),

O termo griotique, de acordo com a perspectiva sinalizada por Niangoran
Porquet, antropólogo e dramaturgo costa-marfinense, traduzia um conceito
literário e artístico de teatro apresentado como representativo de
especificidades do teatro negro africano. Ao espelhar-se na arte
performática griot, a experiência griotique reivindicou uma síntese entre
poema, drama e narrativa curta, estabelecendo, portanto, um "teatro total",
resultante da integração entre o verbo, a expressão corporal, a música, a
poesia, a dança e a recitação. (2007, p. 109).

Sidó é a griote fantástica que vive navegando pelas águas do rio, sendo detentora de vozes poéticas que enredam os espectadores ao fazer emergir histórias e memórias ribeirinhas, também denúncias de ataques sofridos pelo Velho Chico e seu entorno. Há na narrativa fílmica um personagem que, conforme conta Sidó, age como um líder revolucionário que brada quanto ao tratamento recebido pelo rio, suas águas e suas bordas, denunciando ações criminosas e o descaso do governo e da sociedade quanto a todas as mazelas que atacam o Velho Chico.

No filme, há momentos da narrativa em que outras personagens do imaginário se presentificam, como quando o menino Tonho, neto da mística Penha (a atriz Regina Dourado), ao mergulhar nas águas do Velho Chico, afirma ter visto o Nego d'Água e dá as suas características físicas, de modo semelhante ao que é repassado em outras narrativas de ribeirinhos que habitam as margens do rio. Tonho diz ter visto o Nego d'Água, "daquele dos vermelhos", considerado o mais ativo e "danado", isto é, o mais temido e respeitado pelas pessoas. Há também o Minhocão, outra personagem fantástica, um surubim velho, já sem barbatanas, ao qual lhe é atribuída a culpa por ter afundado o barco no qual se encontrava a personagem Henrique, que estava voltando de uma viagem de trabalho como fotógrafo do Velho Chico. Tal fato é testemunhado por uma das personagens, a qual conta ter visto o tal surubim velho, que até já perdeu as barbatanas, afundar o barco, no momento em que se choca com ele, pois há mais de cem anos esse minhocão vem "atazanando" a vida do povo, segundo ela nos informa em seu relato sobre o naufrágio do barco. 
A personagem Sidó é conhecedora de tudo que se passa. No momento em que narra, ela não apenas apresenta os fatos, mas emite um conhecimento sobre eles, algo que sabe além do que testemunha. Assume, então, um papel de onisciência ao narrar os fatos. Sidó é a voz que induz à reflexão, inclusive para algumas questões de tratamento quanto às temáticas abordadas no filme. Ela conduz o espectador para não apenas conhecer o que ocorreu, mas também a pensar sobre. Assim, não há como não se refletir sobre a importância da cultura oral, da sabedoria popular abordada pelo filme e que se faz tão presente e necessária para a própria sobrevivência dos indivíduos que integram essas comunidades.

Pode-se ressaltar, nesse âmbito, a forte presença da fé, por meio das rezas e práticas de costumes desempenhadas pelas personagens. A benzedura, a reza para tirar o olhado e curar as moléstias, a capacidade de perceber maus presságios são aspectos abordados e que se manifestam no filme por meio de atitudes de personagens como Penha. As crenças populares também são trazidas no filme, como no momento em que uma personagem está em trabalho de parto e a personagem Penha, no papel de sua mãe e parteira, realiza a prática da benzedura, rezando a filha com ramos de plantas e também pedindo para que ela reze a fim de que seu filho nasça logo. Tal fato reforça a fé do povo e a presença das benzedeiras, muito comum entre os povos ribeirinhos, configurando-se num costume tradicional entre eles.

Como se observa, nas comunidades cuja cultura popular tem uma representatividade considerável, as benzedeiras com suas rezas possuem um papel de destaque e de respeito, uma vez que, com suas práticas, rezas e remédios caseiros são, em muitos casos, a única forma de perspectiva de cura, de resolução de problemas quanto à saúde física e mental, tendo em vista que a presença da saúde pública nesses rincões do nosso país nem sempre se torna possível e frequente. Ademais, pode-se se dizer que as rezadeiras ou benzedeiras também se utilizam dessas práticas como forma de solucionar muitas intempéries nessas comunidades, não apenas as relacionadas à saúde, mas aquelas relacionadas às relações amorosas, à falta de chuva, às pragas da lavoura, dentre outras.

Tudo isso se configura na força da fé, da oração, das crenças populares que compõem a pluralidade cultural do nosso povo, porque, como se pode observar, há a mistura da reza - que abraça, na maioria das vezes, em seu texto a alusão a santos e entidades da mata, do Candomblé, de outras práticas não cristãs - com o uso de ervas, plantas sagradas da sabedoria ancestral indígena e afrodescendente. Essas rezadeiras e benzedeiras podem ser consideradas como uma espécie de pajé da cultura indígena ou mesmo de um curador, detentor de conhecimentos sobre a cura também da cultura de origem africana, como é o caso da personagem Penha. Essas rezas e benzeduras vêm, na maioria das vezes, acompanhadas do uso de bebidas feitas à base de ervas e, ainda, seguidas da prática de rituais religiosos. Afinal, quem nunca foi ou viu alguém ser rezado de "mau olhado", "espinhela caída" ou outras moléstias similares tão corriqueiras nessas comunidades Brasil afora, inclusive naquelas que margeiam o Velho Chico como essas apresentadas no filme? 
Além disso, enquanto Tonho, o neto de Penha, vai buscar a bacia para aparar a criança que estava para nascer, ele reclama ter demorado para encontrar a bacia devido ao fato de o Romãozinho tê-la escondido. Este é outro personagem do imaginário que também habita as margens do Velho Chico, fazendo parte de sua memória coletiva. $\mathrm{O}$ Romãozinho é um ser encantado, um moleque travesso que vive aprontando coisas como esconder objetos, jogar lixo e estrume nas panelas com comida, dentre outras traquinagens. Outro momento de manifestação das práticas tradicionais que habitam a memória da comunidade ribeirinha apresentada na narrativa fílmica é quando Penha, ao ver sua filha com enjoo durante a gravidez, pede para que ela cheire a cueca de seu marido com o propósito de que o enjoo passe. Essa é mais uma prática tradicional trazida na narrativa, dentre tantas outras que podem ser confirmadas durante a tecedura da trama fílmica.

A personagem Penha é uma das que mais remete o espectador ao universo das práticas tradicionais e religiosas que residem na memória coletiva do lugar. Ela tem maus presságios, sentimentos ruins de acordo com determinadas circunstâncias, revelando a sensibilidade mística que as rezadeiras e benzedeiras possuem. Por não poder ir ao santuário de Bom Jesus da Lapa - cidade ribeirinha do Velho Chico que é cenário de uma das maiores romarias do Brasil em devoção ao senhor Bom Jesus - pagar uma promessa, Penha envia ao santuário da Lapa, dentro de uma cabaça, através do leito do Velho Chico, o pedido de uma graça ou mesmo o agradecimento por seu alcance. Observa-se, nesse momento, que essa é mais uma prática tradicional dos povos da região que, quando não conseguem ir ao santuário pagar as suas promessas, deixam que o Velho Chico as levem dentro de uma cabaça até lá.

\section{Sidó, a guardiã da memória e da tradição}

A canoa Sidó representa a tradição, a sabedoria, aquilo que já não se tem mais acesso com facilidade em todos os momentos e, por isso, necessita ser preservada e respeitada. É uma representação simbólica da memória. Isso é percebido quando uma personagem, o dono da canoa, afirma que ela não é apenas um toco de pau, uma canoa qualquer, mas é uma canoa de um pau só, que já não existe mais na região a madeira da qual ela foi feita e que ela foi trazida por um índio. Esse diálogo entre essas duas personagens da história fílmica nos remete à necessidade de se atentar para o respeito às tradições, ao passado que busca servir ao presente, como afirma Le Goff (2003, p. 471): "A memória, na qual cresce a história, que por sua vez a alimenta, procura salvar o passado para servir ao presente e ao futuro".

Entende-se, a partir dessa assertiva de Le Goff (2003) que a memória faz parte também do presente, que necessita ser preservada, tendo em vista a sua importância para o entendimento dos fatos da atualidade e, ainda, da própria consolidação das identidades culturais. Quando, na narrativa do filme, a personagem afirma que a canoa lhe foi trazida por um índio, vale considerar a importância da confluência das matrizes culturais na 
formação das identidades, especialmente a dos povos ribeirinhos, a qual, além da influência portuguesa, apresenta em sua trama identitária, a cultura indígena e a afrodescendente.

Nesse ínterim, sobre a memória e sua importância, vale ainda ressaltar Ricoeur (2007), que a considera como sendo aquela construída a partir de uma coletividade que une passado, presente e futuro, orientando a própria passagem do tempo e o posicionamento de um povo diante de sua cultura e tradições. Esse diálogo entre as duas personagens a respeito da origem e da importância da canoa Sidó vem ratificar toda essa relação com a importância de preservação de uma memória coletiva pautada na diversidade, na pluralidade cultural. Cuidar da canoa velha, abandonada, dar uma "ajeitadazinha nela", remete à necessidade de se cuidar da memória, das tradições, de se atentar para a importância da sabedoria ancestral para a sociedade, nesse caso, as sociedades de tradição oral como essas comunidades ribeirinhas. Não se pretende aqui desconsiderar a importância da memória e da sabedoria popular também para as sociedades pautadas na cultura da escrita e, agora, do ciberespaço e do audiovisual. Porém, seria uma outra discussão em outro momento e abordagem.

Em vários trechos a obra fílmica em estudo nos remete, principalmente por meio da personagem Sidó, para a importância dessa preservação da memória coletiva e que é repassada por meio da oralidade de geração a geração. É isso, portanto, que nos identifica e nos faz perceber quem somos, o que fazemos e como nos representamos, pois conforme versa Lucília Delgado (2010):

A memória é base construtora de identidade e solidificadora de consciências individuais coletivas. É elemento constituído do autorreconhecimento como pessoa e/ou como membro de uma comunidade pública, como uma nação, ou privada como uma família. A memória é inseparável da vivência da temporalidade, do fluir do tempo e do entrecruzamento de tempos múltiplos. A memória atualiza o tempo passado, tornando-o tempo vivo e pleno de significados no presente. (DELGADO, 2010, p. 38).

Os aportes alusivos à importância da memória e da tradição, por meio da canoa Sidó, são uma constante em todo o filme. Mas não são as únicas abordagens quanto a essa discussão. As práticas de tradição oral e religiosa são diversas e assumem, na narrativa, uma força que marca a resistência do povo ribeirinho para manter a sua cultura viva e forte, inclusive em relação aos hábitos de conservação do rio, do respeito para com as suas águas, mistérios e encantamentos.

Há denúncias por parte de personagens quanto à degradação que o Velho Chico vem sofrendo em diversos aspectos: poluição, assoreamento, exploração desordenada de sua fauna aquática, da vegetação de suas margens, de suas águas para diversas atividades, dentre outros. Quando, ao falar de Sidó, uma das personagens diz que a madeira da qual ela é feita já nem existe mais, a personagem nos remete ao desmatamento de suas margens para a navegação dos navios a vapor, fato que contribuiu para a extinção de muitas espécies que compunham a mata e a caatinga, quando não as dizimou por completo. E tudo isso, com uma denúncia focada na possibilidade da morte do Velho Chico, 
que não seria apenas a morte física de suas águas e de uma região, mas a morte de toda uma cultura, de todo um povo, suas tradições e história.

\section{Sidó e sua viagem pela cultura das bordas do Velho Chico}

Todos esses aspectos abordados nessas reflexões reforçam a necessidade da luta e da resistência contra o afogamento das tradições por águas hegemônicas, que tendem a desmerecer e a não se preocupar com as culturas populares e sua pluralidade identitária. Culturas estas que podem ser nomeadas, de acordo com Jerusa Pires Ferreira (2010) como cultura das bordas. Para a autora, acerca dessa cultura das bordas, vem

[...] enfatizar a exclusão do centro, aquilo que fica numa faixa de transição entre uns e outros, entre as culturas tradicionais reconhecidas como folclore e a daquelas que detêm maior atualização e prestígio, uma produção que se dirige, por exemplo, a públicos populares de vários tipos, inclusive àqueles das periferias urbanas. (FEREIRA, 2010, p. 30).

Outrossim, para que não ocorra uma desfiguração desse espaço cultural, seu enfraquecimento ou até extinção, é preciso amparar-se em estratégias de resistência como esses aportes do filme, tendo em vista que "A voz enlouquecida da tradição nos remete também a noções de 'resistência' e de resguardo, de pertença, instalando-se mais uma vez toda uma discussão sobre o político no corpo do poético e suas transferências" (FERREIRA, 2003, p. 66).

Todo esse processo de resistência por meio da manutenção das tradições e do avivamento da memória contribui diretamente para a consolidação de uma identidade que se fortalece por meio do reconhecimento da força da cultura oral ribeirinha pela sua gente. Ao enfatizar em sua identidade as suas tradições e memórias, o Velho Chico se fortalecerá e não morrerá tão cedo, seguirá levando adiante uma cultura que, mesmo situando-se na borda entre uma cultura de prestígio detentora de reconhecimento e maior valor, e entre a considerada como folclórica, não se deixará afogar. Isso porque essa cultura das bordas, nomeada assim por Jerusa Pires Ferreira (2010), é uma produção feita e direcionada a públicos populares de diversos tipos, inclusive àqueles que habitam as periferias urbanas, público esse que resiste e luta pela preservação de sua memória e pela escuta das vozes poéticas de sua tradição. Ademais, a memória identitária dessas pessoas tende a se consolidar de modo mais fiel às suas culturas, pois:

De fato, memória e identidade se entrecruzam indissociáveis, se reforçam mutuamente desde o momento de sua emergência até sua inevitável dissolução. Não há busca identitária sem memória e, inversamente, a busca memorial é sempre acompanhada de um sentimento de identidade, pelo menos individualmente. (CANDAU, 2011, p. 19).

As personagens, aqui trazidas nessa discussão, emitem vozes poéticas que muito bem podem ser compreendidas pela comunidade narrativa ribeirinha, pois são vozes que se abraçam a uma série de aspectos performáticos, como entonações, pausas, 
sonoridades. Basta escutar Sidó em suas narrativas, ou mesmo outras personagens do filme e ainda narradores diversos que vivem na beira do rio, para que o espectador se enrede nessa trama performática. São, portanto, vozes de uma poética movente, porque trazem em si um universo de tradições, costumes, crenças e valores que se reconfiguram por meio de um entrelaçamento cultural plural, diverso e perene, como as próprias águas do rio. São vozes que contam, cantam e encantam quando exprimem os anseios, saberes e fazeres de uma cultura das bordas que, conforme versa Ferreira (2010), ocupa os espaços periféricos da beira de um sistema cultural etnocêntrico. Isso porque:

[...] em espaços não consagrados do mundo urbano, se desenrola toda uma cultura que absorve e é absorvida, criando regiões imantadas que nos permitem pensar em temas, autores, textos a pedir sempre novos parâmetros de avaliação, em regime de movimento e descobertas. (FERREIRA, 2010, p. 12-13).

As personagens do imaginário ribeirinho estão presentes na narrativa e assumem atitudes humanas. Mesmo que as características físicas não sejam tão fiéis às dos homens, as suas atitudes e sentimentos Ihes são comuns. Em diálogo entre a personagem Abel e o menino Tonho, nota-se a prática de dar fumo ao Nego d'Água, de agradá-lo e fazer amizade. Assim como nas narrativas orais de pescadeiras e pescadores da região de Xique-Xique na Bahia, como pude comprovar em pesquisas realizadas para minha dissertação de mestrado, pode-se perceber essa prática de agradar, fazer amizade com o Nego d'água, o qual possui as mesmas características físicas trazidas tanto pelas personagens do filme como pelos narradores e narradoras da beira do rio. Esse ser imaginário vive em todo o São Francisco e tem atitudes semelhantes nas diversas narrativas de diversas regiões. Ele se humaniza a tal ponto de se apaixonar por mulheres ribeirinhas, também por cortar redes, virar canoas quando lhe desagradam, dentre outras atitudes.

Esses seres compõem o imaginário ribeirinho e fazem parte do universo tradicional de sua gente. São usados para ratificar valores e normas de boa conduta, como não realizar xingamentos, não praticar ações de maldade, não agir de má-fé e não possuir má índole, pois se agirem assim, poderão sofrer represálias do Nego d'Água e dos outros seres, inclusive do Velho Chico, que pode se revoltar, enfurecendo suas águas, criando redemoinhos e armadilhas capazes de fazer sumir barcos, canoas e pessoas. Nas narrativas, o Velho Chico tem desejos e sentimentos humanizados. Quando alguém morre afogado, por exemplo, é preciso esperar que ele devolva o corpo e, geralmente, é necessário fazer vigília e súplicas para que essa devolução não demore.

A Mãe d'Água também, assim como o Nego d'Água e o Velho Chico, aparece como um ser encantado que é metade mulher e metade peixe, com atitudes de gente. Ela vive em todo o curso do Rio São Francisco e também recebe oferendas, é respeitada pelos ribeirinhos que, assim como fazem com os demais, buscam lhe agradar para não sofrer represálias, como por exemplo, ter a suas crianças raptadas para viverem com ela no fundo 
do rio. É preciso, pois, presenteá-la com pentes, sabonetes, perfumes e joias. De atitude semelhante a esses seres trazidos nestes últimos parágrafos é o Minhocão, um surubim velho sem barbatanas que precisa ser agradado e respeitado. O ribeirinho tem de tomar cuidado com ele para que não sofra as consequências de sua ira se ele for contrariado. No filme, a motivação do naufrágio sofrido pela personagem Henrique, como já citado anteriormente, foi o Minhocão que se chocou contra a embarcação num momento de temporal causando o seu emborcamento e naufrágio.

Outra espécie de griote do lugar é Tonha, que, assim como Sidó, mantém as tradições e repassa a sua sabedoria extraída da memória coletiva, pois esta lhe foi repassada de gerações anteriores por meio de seus pais e avós. Tonha preocupa-se com isso e retransmite ao neto, no momento em que lhe diz estar na hora de ele saber das coisas. Nesse momento, ela lhe fala sobre a necessidade de se escutar a voz das coisas, dos bichos, de ter sabedoria para perceber isso.

Sidó e Tonha são guardiãs da memória, narram, repassam, contam. A canoa traz uma representação simbológica quando lhe é conferida uma longevidade atravessando gerações, passando de dono para dono - embora, na narrativa, ela (Sidó) já reconheça a necessidade de fazer a passagem dessa vida e peça para que Abel, seu dono, organize logo um ritual para queimá-la em uma fogueira na margem do rio. E dessa forma, esse ritual de passagem ocorre em certa parte da narrativa fílmica. É uma personagem que remete o espectador a toda uma simbologia e fantasia. A sua própria constituição já lhe confere essas qualificações fantásticas e sobrenaturais. O conhecimento a faz ser atemporal e ter muitas respostas, explicações diante dos acontecimentos.

O próprio fato de Sidó ser uma canoa já oportuniza essa relação com a viagem da memória pelos tempos, pelas águas da tradição. Por meio dela, pode-se navegar rumo ao conhecimento dos fatos, da história. Sidó é a canoa, o elemento que leva ao saber memorialístico pelas suas narrativas, pelo conhecimento que detém advindos de tantas travessias feitas nos cunhos da história. Com quantos paus se faz uma canoa? Esta é uma pergunta comum feita por aí, mas há outra que convém ser feita aqui nessas reflexões: com quantas memórias se faz uma canoa? Com quantas memórias se constitui a canoa Sidó?

São questionamentos que nos levam a refletir sobre a sabedoria transmitida por meios das práticas culturais advindas dessa riqueza que é o mosaico das identidades culturais. $\mathrm{Na}$ construção de uma canoa, no ato de sua feitura, são realizados diversos outros atos que integram a cultura, não apenas o modo de construir a canoa, - o que demanda a transmissão do saber, do ofício de canoeiro - mas uma série de memórias, de práticas e costumes são retransmitidos por meio de narrativas, histórias e lendas. E a canoa que está sendo feita, assim como Sidó - analisando por um lado simbológico - passa, a partir desse momento, a integrar essa comunidade narrativa, escutando e transmitindo ensinamentos. É possível dizer, ou mesmo brincar dessa forma, porque na canoa, muitas coisas ocorrem, muitas histórias são construídas, muitas memórias são transmitidas.

Não é à toa que se escutem perguntas como essas supracitadas, pois esses paus que 
fazem uma canoa representam toda essa confluência cultural que navega pelo leito das memórias e das histórias, contribuindo, assim, para a consolidação das identidades culturais que, conforme Hall (2000), se estabelecem a partir das relações com outras culturas, com o meio e suas influências. A canoa Sidó passa a representar essa possibilidade de movência do homem e da liquidez de suas identidades, pois ela permite trazer e levar todo esse conjunto de saberes e tradições, ela coloca o canoeiro - na obra fílmica representada pela personagem Abel - em contato com essa confluência de culturas. A viagem de Abel por todo o curso do rio vem representar muito além da possibilidade de conhecer muitos lugares ribeirinhos, mas também uma viagem pela diversidade cultural desses lugares, deixando suas histórias, suas memórias e trazendo, tendo Sidó como testemunha, muitas das histórias e memórias dos povos dos lugares por onde andou. Com isso, passa a contribuir para a perenidade da construção de sua identidade e das identidades dos povos dos lugares, uma vez que acabam absorvendo e retransmitindo o que aprende, pois a identidade cultural é "[...] uma celebração móvel: formada e transformada continuamente em relação às formas pelas quais somos representados ou interpolados nos sistemas culturais que nos rodeiam" (HALL, 2000, p. 13).

Convém ressaltar acerca das identidades, que estas não podem se configurar de maneira fixa, estável, pois elas se constroem apoiando-se em um processo contínuo de identificação, que, a cada momento, aprimora-se e se completa. Isso porque "as identidades, concebidas como estabelecidas e estáveis, estão naufragando nos rochedos de uma diferenciação que prolifera" (HALL, 2003, p. 43). Pelas águas do Velho Chico, em que navega a canoa Sidó e vivem tais seres fantásticos e maravilhosos do imaginário popular, pode-se afirmar que navegam tradições, emergem-se memórias que são retransmitidas e contribuem para essa movência das identidades culturais dos povos ribeirinhos, como os seres trazidos no filme, porque elas (as identidades) são, portanto, segundo Bauman (2005), líquidas e fluidas, chegando a assumir formas que se alteram e se modificam numa espécie de incompletude perene.

\section{Considerações finais}

Portanto, pode-se chegar a uma finalização momentânea dessas reflexões, considerando que tais personagens apontadas influenciam diretamente na vida da maioria dos ribeirinhos, os quais tomam os ensinamentos e exemplos das narrativas como modelos de conduta e de vivência. São elementos ideológicos, valores e crenças que contribuem para a formação das identidades culturais desses povos. Além disso, essas personagens fantásticas e maravilhosas do filme, ou mesmo das narrativas orais analisadas, fazem partem do cotidiano dos ribeirinhos das margens do Velho Chico, tornando-se seres integrantes dessas comunidades, nas quais uma grande maioria das pessoas trazem um testemunho de histórias que viveram ou ouviram contar sobre tais personagens.

Em todo o momento nos depoimentos, narrativas orais contadas por ribeirinhos e também nas cenas da obra fílmica, fica marcada a importância das tradições para o 
cotidiano do povo ribeirinho que encontra na fé, nas crenças e nas próprias personagens do seu imaginário, elementos que o fortalecem e o impulsionam a continuar (re)existindo nessas margens, nessas bordas desfavoráveis, como já apontou Jerusa Pires Ferreira (2010) nesse estudo.

Sidó, o Velho Chico e os seus companheiros fantásticos e maravilhosos do imaginário ribeirinho fazem parte de uma cultura rica e plural que encanta e fascina, mas que ao mesmo tempo tende a sofrer um apagamento ou inferiorização por estar, ainda, nesse entre-lugar das bordas, das margens. Porém, pela força dessa cultura, pela sua capacidade de reinventar, de fortalecer e não deixar morrer a transmissão da memória entre os tempos, sente-se que ela (a cultura das bordas) segue o curso de águas, muitas vezes turbulentas, rumo ao centro que, por mais que haja uma tendência em repelir tais culturas feitas e direcionadas a públicos populares, não há como negar a sua força e importância na construção desse mosaico cultural que é a identidade de nossa gente, de nossa nação.

\section{Referências}

BARZANO, Marco A. L. Griôs: dobras e avessos de uma ONG, Pedagogia, Ponto de Cultura. Feira de Santana: UEFS Editora, 2013.

BAUMAN, Zygmunt. Identidade: entrevista a Benedetto Vecchi. Trad. de Carlos Alberto Medeiros. Rio de Janeiro: Jorge Zahar, 2005.

CANDAU, Joel. Memória e Identidade. Trad. de Maria Lúcia Ferreira. São Paulo: Contexto, 2011.

DELGADO, Lucília de Almeida Neves. História oral: memória, tempo, identidades. 2. ed. Belo Horizonte: Autêntica, 2010.

ESPELHO D’Água: uma viagem no Rio São Francisco. Direção de Marcos Vinícius Cezar. Rio de Janeiro: Copacabana Filmes, 2004. 1 DVD (110min.).

FERREIRA, Jerusa Pires. Armadilhas da memória e outros ensaios. São Paulo: Ateliê Editorial, 2003.

FERREIRA, Jerusa Pires. Cultura das bordas: edição, comunicação, leitura. Cotia, SP: Ateliê Editorial, 2010.

HALL, Stuart. A Identidade cultural na pós-modernidade. Trad. de Tomaz Tadeu da Silva, Guaracira Lopes Louro. 4. ed. Rio de Janeiro: DP\&A, 2000.

HALL, Stuart. Da Diáspora: identidades e mediações culturais. Trad. de Adelaine La Guardia Resende [et al.]. Belo Horizonte: Editora UFMG; Brasília: Representação da UNESCO no Brasil, 2003.

LE GOFF. História e memória. Trad. de Bernardo Leitão et al. 5. ed. Campinas, SP: Editora da UNICAMP, 2003.

QUEIROZ, Amarino de oliveira. As inscrituras do verbo: dizibilidades performáticas da palavra poética africana. 2007. 310 f. Tese (Doutorado em Teoria da Literatura) Centro de 
Artes e Comunicação, Programa de Pós-Graduação em Letras, Universidade Federal de Pernambuco, Recife, 2007.

RICOEUR, Paul. A memória, a história, o esquecimento. Trad. de Alain François [et al.]. Campinas, SP: Editora da UNICAMP, 2007.

TODOROV, Tzevtan. Introdução à literatura fantástica. 4. ed. São Paulo: Perspectiva, 2014.

ZUMTHOR, Paul. Introdução à poesia oral. Trad. de Jerusa Pires Ferreira, Maria Lúcia Diniz Pochat e Maria Inês de Almeida. Belo Horizonte: Editora UFMG, 2010.

\section{NOTAS DE AUTORIA}

Nerivaldo Alves Araújo (neriaraujo@hotmail.com) é Doutor em Literatura e Cultura pela Universidade Federal da Bahia (UFBA/2015). Mestre em Estudo de Linguagens pela Universidade do Estado da Bahia (Uneb/2010). Graduado em Letras pela Universidade do Estado da Bahia (Uneb/1998). Professor Adjunto e docente permanente do Programa de Pós-Graduação em Estudo de Linguagens (PPGEL/Uneb, DCH I), exercendo, atualmente, a função de Coordenador de Colegiado do respectivo Programa. Autor do livro Poética oral do Samba de Roda das Margens do Velho Chico.

\section{Como citar esse artigo de acordo com as normas da ABNT}

ARAÚJO, Nerivaldo Alves. O Velho Chico e suas bordas culturais: as vozes poéticas da Canoa Sidó e outras personagens fantásticas do Rio São Francisco no filme Espelho d'água. Anuário de Literatura, Florianópolis, v. 26 , p. 01-13, 2021.

\section{Contribuição de autoria \\ Não se aplica.}

\section{Financiamento}

Não se aplica.

\section{Consentimento de uso de imagem}

Não se aplica.

\section{Aprovação de comitê de ética em pesquisa}

Não se aplica.

\section{Conflito de interesses}

Não se aplica.

\section{Licença de uso}

Os/as autores/as cedem à Revista Anuário de Literatura os direitos exclusivos de primeira publicação, com o trabalho simultaneamente licenciado sob a Licença Creative Commons Attribution (CC BY) 4.0 International. Estra licença permite que terceiros remixem, adaptem e criem a partir do trabalho publicado, atribuindo o devido crédito de autoria e publicação inicial neste periódico. Os autores têm autorização para assumir contratos adicionais separadamente, para distribuição não exclusiva da versão do trabalho publicada neste periódico (ex.: publicar em repositório institucional, em site pessoal, publicar uma tradução, ou como capítulo de livro), com reconhecimento de autoria e publicação inicial neste periódico.

\section{Publisher}

Universidade Federal de Santa Catarina. Programa de Pós-graduação em Literatura. Publicação no Portal de Periódicos UFSC. As ideias expressadas neste artigo são de responsabilidade de seus/suas autores/as, não representando, necessariamente, a opinião dos/as editores/as ou da universidade.

\section{Histórico}

Recebido em: 06/12/2019

Aprovado em: 15/07/2020

Publicado em: 23/02/2021 